\title{
Effect of ERP Implementation on the Company Efficiency - A Macedonian CASE
}

\author{
Jan Devos ${ }^{1}$, Jasmina Rajcanovska ${ }^{1}$, Hendrik Van Landeghem ${ }^{2}$, \\ and Dirk Deschoolmeester ${ }^{3}$ \\ ${ }^{1}$ ELIT Lab, University College West Flanders, Ghent University Association, \\ Graaf Karel de Goedelaan 5, 8500 Kortrijk, Belgium \\ ${ }^{2}$ Technologiepark Zwijnaarde 903, 9052 Zwijnaarde, Belgium \\ ${ }^{3}$ Reep 1, 9000 Gent, Belgium \\ \{jang.devos, hendrik.vanlandeghem, dirk. deschoolmeester\} @ugent.be, \\ rajchanovska@yahoo.com
}

\begin{abstract}
Enterprise Resource Planning (ERP) is slowly find its place in many organizations in Macedonia. The primary goal of an ERP implementation is managing and coordinating all resources, information, and business processes from shared data stores. This paper elaborates on an ERP solution implementation in the Macedonian production sector and the effect it has on the company efficiency. A case study was conducted in a small or medium-sized manufacturing company in Macedonia during a period of seven years and compared to empirical findings of ERP systems implementations in developed countries. Findings show almost similar results. ERP systems implementations require time, money and management commitment and the effect to improve efficiency is embryonic. However it was also noticed that ERP system implementation helps in the transformation of the ownership of the company and in establishing better market competitiveness.
\end{abstract}

Keywords: ERP systems, case study, implementation, SME, developing countries.

\section{Introduction}

Globalization has driven companies to invest most of their resources and time in trying to maintain a competitive level. ERP systems present companies with a opportunity to increase efficiency of existing business processes as well as enabling entirely new business processes throughout organization, thus increasing productivity and reducing cycle time [1]. Motivated by the actuality of ERP implementations in Macedonia, the main goal of this research is to find out whether the implementation of such systems affects the organizational efficiency, and to what extent. The main research questions this research concentrates on are: 1) What is the situation with ERP usage in Macedonia?, 2) What was the reason for decision to implement ERP?, 3) What were the objectives of the ERP implementation? 4) What was the effect of the ERP system implementation on the company?, and 5) How the company changes its efficiency after ERP system implementation? 
The contribution of this work is the analysis of a ex-socialistic enterprise (previously state owned, now privatized) which implemented an ERP solution very early compared to companies similar in size and transformation of ownership. The paper itself is organized in six parts: the first part follows the situation with ERP implementation in Macedonia. The second part begins with a review of literature about the impact of ERP systems on performance of organizations. It continues with presenting the operational (financial) performance measures for ERP impact and the time for experiencing benefits. The third part presents the research methodology beginning with the description of the research framework. Next we bring our findings preceded by a short description of the company and the final part presents the conclusions of the research.

\section{The Situation in Macedonia}

The Republic of Macedonia is located in the central Balkans and gained independence from the former Socialist Federal Republic of Yugoslavia in 1991. The country became a member state of the United Nations in 1993 under the temporary title of "the Former Yugoslav Republic of Macedonia" (FYROM). The turbulent period, in the wake of the break-up of Yugoslavia inevitably impacted the Macedonian economy. In the first years after the independence, the Macedonian economy suffered the loss of large and protected market resulting in steep falls in GDP. Privatizations of state owned enterprises together with foreign investments have been performed quickly since the 90's [2]. Although the above has enabled the development of a stable macro-economic environment, the country has not been as successful in restarting its economic growth [3]. Irrespective of the size, if Macedonian companies want to operate on foreign markets, if their intention is sustainable development and durable success, they should have more efficient organizations and more competing products and services. These attributes are claimed to be achieved through ERP solutions usage. All in all, Macedonian companies in general are more interested in the implementation of software adapted to their work and needs. There is a visible awareness rising among them about the need of investment in software as a business tool. This rise is mostly due to the investments in the telecommunication and banking sector, while the growth of SMEs interest is still not satisfying.

\section{$3 \quad$ Research Methodology}

The objective of this study was to explore in detail the process of implementation and usage of ERP systems in a developing country and interpret the significance of factors that lead to successful implementations. Due to they nature, our research questions can be answered using the case study method [4]. We focused this research at one company and choose for a case study research model [5]. Yin defines the scope of a case study as follows: 'A case study is an empirical inquiry that: investigates a contemporary phenomenon within its real-life context, especially when the boundaries between phenomenon and context are not clearly evident" [4]. Myers stress that the case study research method is particularly well-suited to IS research, 
since the object of study are information systems in organizations, and "interest has shifted to organizational rather than technical issues" [6]. The research follows certain indicators of the company prior and after ERP implementation and from the other side it is a typical case among large ex-socially owned Macedonian companies which implemented ERP system solution very early compared to companies similar to it in size and ownership. Development of this case study was established by analysis of the archival data of the organization as well as analysis of the data gained during the interviews. This particular research relies on a triangulation of the following three techniques: 1) semi-structured interviews with managers (IT and CEO) within the organization, 2) employees' survey intended to test employees' perceptions about the effect of the implemented ERP system, and 3) secondary data analysis of existing organizational data comprising annual financial reports. The financial indicators movement was followed in the period before and after the system implementation. Between- (or across-) method triangulation is where two or more distinct methods are employed to measure the same phenomenon, but from different angles. The rationale is that cumulatively the weaknesses of one research method are offset by the strengths of the others [7]. The questionnaires of the semi-structured interviews and the survey are not included in this paper but can be obtained by the authors. Before continuing with the research it is essential to give a definition for the word "efficiency", as is the basic word that this work relies on. The term used here be explained with the definition from "The Concise Encyclopedia of Economics" which says: "economic efficiency is measured not by the relationship between the physical quantities of ends and means, but by the relationship between the value of the ends and the value of the means'.

\section{$4 \quad$ Findings}

\subsection{The Case Study Company}

The shareholder company Komuna in Skopje is one of the oldest and leading producers for paper and cardboard boxes in the Republic of Macedonia. The computerization of the company started in 1998 when they bought their first computers. Regarding the software, that period the company used several separate applications in finance, accounting and material working. The rest of the processes were performed with no automation, using human hand, machines, paper and telephone. This way of organization of the work produced a lot of inefficiency and errors. Due to misunderstanding and having no control of the work, a lot of mistakes appeared and very often wrong orders were produced that laid in inventory. The company was also receiving complaints by the clients about not respecting of promised deadlines. Perceiving the current situation at that time (1998) and having a long term oriented vision, the company IT team suggested the company management implementation of an ERP system. The reason behind this proposal was implementation of new solution that will offer new functionality. According to IT manager: "the basic need for redesign and reengineering of business software solution build with technology and knowledge 15-20 years ago and in completely different economic climate, led our company to implementation of an integrated information system". 


\subsection{Findings from the Interviews with the CIO and the CEO}

The CIO stressed that the company had milieu of goals with the implementation of the ERP system: "gaining of technological benefits, effectiveness, consistency, reaching integrated system, control, efficiency, preciseness, timeliness, operating costs reduction, rationalization within certain departments, providing quality finished work, respecting of proposed deadlines". Realization of all these goals was envisaged with implementation of customized ERP solution from Macedonian vendor Artisoft. The implementation (phased approach) started with the implementation of the financial module in April 2000. After this implementation, the complete financial work was transferred to this module. Phase by phase the following modules were added: material accounting, warehouse accounting, sales, assets, production (technical preparation of working orders), HR, personnel files, payroll and internal security data flow with consistency. Due to internal management restructuring, the second and the third phase of the implementation which perceived detailed functionalities within the production module as well as implementation of Decision Support System (DSS) tools (graphical presentations, trends, and data mining tools) were not realized. Due to the same factors Komuna also continues to use an old independent payroll application, besides having that functionality in the ERP system. Technical acceptance of the system was made in January 2003. The employees were also partially involved during the implementation phase, because of the opinion that "being detail oriented they didn't have vision of the whole system". Still they were consulted about the specific processes/procedures of their work. After the implementation, trainings for the users were conducted several times during the implementation phase and partially on departments' level after the implementation. Manuals were prepared by Artisoft and distributed to the users.

User comments afterwards were various. They went from satisfaction to complete dissatisfaction. Some reaction on department level was evident, which aroused by the fear that the work can be controlled: control of how much is produced, how long it stands in the warehouse. This is very much connected to the socio-political approach to user resistance proposed by Markus [8]. According to Markus, users resist to a system if they perceive that the project could reduce their official or unofficial power in the organization e.g. people show resistance if they feel loss of power and do not show resistance if they feel they gain power. The CEO explained during the interview that there were no metrics established prior to ERP implementation for determining how well the company achieved ERP implementation objectives and no cost benefit analysis was performed after. According to him, implementing the ERP system, the following business processes of the company became more competitive: marketing including sales and supply, production process in terms of better organization and monitoring of the financial management. Regarding the benefits brought by the system, they are reflected in improved monitoring level of strategic information about Komuna's activities. The system provides information regarding monitoring of activities that did not existed before the implementation, such as instant access to customized information to every user regardless of location and time (on 24/7 bases). Most significant monitoring information is about sales, financial flow, supply of materials for production, work orders and production itself. Other benefits that Komuna gained due to the system implementation include better visibility on 
creditors and debtors which increased up to $25 \%$, improvement of the history data management up to $75 \%$, reduction of the delivery time to $33 \%$ from average 15 days to 10days reducing errors in planning process, decrease of the production cycle, optimization of the administration cycle with cutting of the overlapping functions and concurrently decreasing the administration cycle which was all the time needed to monitor, measure plan and trigger the corrective measures. The latter was one of the areas where the impact was the biggest.

\subsection{Findings from the Employees' Survey}

The influence of the system to employees work and their perception about the changes it brought was measured through a survey. The survey was based on a questionnaire consisted of six single answer questions. In total, 50 questionnaires were delivered through different sectors of the company. Out of them only 35 were received back, meaning that technically the survey was conducted on a sample of 35 employees. According to the answers, the respondents belonged: $8.6 \%$ to the management/operations sector, $14.3 \%$ to the finance sector, $8.6 \%$ to the material accounting, $11.4 \%$ to the warehouse, $14.3 \%$ to the sales, marketing $11.4 \%$, production $25.7 \%$ and $\mathrm{HR} 5.7 \%$.

The first question they were asked was "if their work position requires use of the software system (Q2)". $62.9 \%$ of them answered that it does require, $22.9 \%$ that it doesn't require, and $14.3 \%$ that "it is up to them". To the question "How much do you use the system (Q3)" 51.4\% of them responded "Often", 25.7\% "Sometimes", $11.4 \%$ "Never" and 11.4\% "Rarely". If a cross tabulation is made between these two questions the following result in table 1 is received.

Table 1. Cross tabulation of question 2 and question 3

\begin{tabular}{|l|l|l|l|l|l|l|}
\hline \multicolumn{2}{|l|}{ Cross tabulation of question 2 and 3} & \multicolumn{4}{|l|}{ Question 3 (How much do you use it?) } & \\
\cline { 3 - 7 } & & Often & $\begin{array}{l}\text { Some- } \\
\text { times }\end{array}$ & Rarely & Never & Total \\
\hline $\begin{array}{l}\text { Question 2 (Does your } \\
\text { work position require use } \\
\text { of the software system?) }\end{array}$ & Yes & $77.3 \%$ & $22.7 \%$ & & & $100.0 \%$ \\
\cline { 2 - 7 } & $\begin{array}{l}\text { It is up } \\
\text { to me }\end{array}$ & $20.0 \%$ & $40.0 \%$ & $20.0 \%$ & $20.0 \%$ & $100.0 \%$ \\
\hline Total & & $51.4 \%$ & $25.7 \%$ & $11.4 \%$ & $11.4 \%$ & $100.0 \%$ \\
\hline
\end{tabular}

When asked the question to which extent did the system affect the difficulty of accomplishing of your tasks (question 5), 62.9\% answered "it made it easier", 2.9\%"it made it more complicated" and 34.3\% "didn't change anything". Almost $73 \%$ of the employees, whose work position requires using of the software system and $80 \%$ of the ones saying that using of the system is up to them, answered that the system made the accomplishing of their tasks easier for them. A cross tabulation of question 5 with question 2 is shown in table 2.

Having in mind the answers per work position requirement of usage of the software system, a cross tabulation is shown in table 3 and the conclusion can be made that employees feel fairly empowered about accomplishing of their tasks. 
Table 2. Cross tabulation of question 2 and question 5

\begin{tabular}{|c|c|c|c|c|c|}
\hline \multirow{2}{*}{\multicolumn{2}{|c|}{$\begin{array}{l}\text { Cross tabulation of question } \\
22 \text { and } 5\end{array}$}} & \multicolumn{3}{|c|}{$\begin{array}{c}\text { Question } 5 \text { (To which extend did the } \\
\text { system affect the difficulty of } \\
\text { accomplishing your tasks? }\end{array}$} & \multirow[b]{2}{*}{ Total } \\
\hline & & $\begin{array}{l}\text { It made it } \\
\text { more } \\
\text { easier }\end{array}$ & $\begin{array}{l}\text { It made it } \\
\text { more } \\
\text { complicated }\end{array}$ & $\begin{array}{l}\text { Didn't } \\
\text { change } \\
\text { anything }\end{array}$ & \\
\hline \multirow{3}{*}{$\begin{array}{l}\text { Question } 2 \text { (Does your } \\
\text { work position require } \\
\text { use of the software } \\
\text { system?) }\end{array}$} & Yes & $72.7 \%$ & $4.5 \%$ & $22.7 \%$ & $100.0 \%$ \\
\hline & No & $25.0 \%$ & & $75.0 \%$ & $100.0 \%$ \\
\hline & $\begin{array}{l}\text { It is up } \\
\text { to me }\end{array}$ & $80.0 \%$ & & $20.0 \%$ & $100.0 \%$ \\
\hline Total & & $62.9 \%$ & $2.9 \%$ & $34.3 \%$ & $100.0 \%$ \\
\hline
\end{tabular}

Table 3. Cross tabulation of question 2 and question 6

\begin{tabular}{|c|c|c|c|c|c|c|}
\hline \multirow{2}{*}{\multicolumn{2}{|c|}{$\begin{array}{l}\text { Cross tabulation of question } \\
\qquad 2 \text { and } 5\end{array}$}} & \multicolumn{4}{|c|}{$\begin{array}{l}\text { Question } 6 \text { (Does the system make you feel } \\
\text { more empowered about accomplishing your } \\
\text { tasks? }\end{array}$} & \multirow[b]{2}{*}{ Total } \\
\hline & & $\begin{array}{c}\text { Feel more } \\
\text { confident } \\
\text { about the } \\
\text { quality of } \\
\text { my job }\end{array}$ & $\begin{array}{l}\text { It is } \\
\text { interesting } \\
\text { for my } \\
\text { tasks }\end{array}$ & $\begin{array}{l}\text { I feel } \\
\text { the } \\
\text { same }\end{array}$ & No & \\
\hline \multirow{3}{*}{$\begin{array}{l}\text { Question } 2 \text { (Does your } \\
\text { work position require } \\
\text { use of the software } \\
\text { system?) }\end{array}$} & Yes & $31.8 \%$ & $40.9 \%$ & $22.7 \%$ & $4.5 \%$ & $100.0 \%$ \\
\hline & No & & $25.0 \%$ & $75.0 \%$ & $37.5 \%$ & $100.0 \%$ \\
\hline & $\begin{array}{l}\text { It is } \\
\text { up } \\
\text { to } \\
\text { me }\end{array}$ & $40.0 \%$ & $40.0 \%$ & $20.0 \%$ & $20.0 \%$ & $100.0 \%$ \\
\hline Total & & $25.7 \%$ & $37.1 \%$ & $34.3 \%$ & $14.3 \%$ & $100.0 \%$ \\
\hline
\end{tabular}

Change of the speed in doing the work compared to before the system implementation is evidenced by $34.3 \%$ of the respondents as "a lot faster", $45.7 \%$ say that they do their work "a bit faster" compared to before the system implementation and $20 \%$ say that there is "no change". All in all $80 \%$ of the respondents say that the system gave effect in speeding the process of doing the work.

\subsection{Findings from the Company's Annual Reports}

As third source of information, Komuna's annual reports (2001-2008) received from the Macedonian Stock Exchange were used. After extracting and processing the data from the reports and converted to financial indicators, the results are shown in table 4.

The only indicator which shows characteristic movement through the years is Labor Productivity. Following this indicator constant inclination can be noticed which indicates increasing of the employee productiveness. Employees' number declines from 473 in 2001 to 305 in 2008; however the results show that they are becoming more productive. All in all in this case financial indicators do not give good information for making firm conclusions about the effect of the ERP system implementation of the company efficiency. 
Table 4. Financial indicators

\begin{tabular}{|l|c|c|c|c|c|c|c|c|}
\hline & 2001 & 2002 & 2003 & 2004 & 2005 & 2006 & 2007 & 2008 \\
\hline Inventory/Sales & 0.17 & 0.12 & 0.15 & 0.14 & 0.15 & 0.14 & 0.14 & 0.14 \\
\hline $\begin{array}{l}\text { Inventory/Total } \\
\text { Assets }\end{array}$ & 0.18 & 0.13 & 0.16 & 0.14 & 0.14 & 0.13 & 0.14 & 0.15 \\
\hline $\begin{array}{l}\text { Labour } \\
\text { Productivity }\end{array}$ & 1.41 & 1.58 & 1.53 & 1.49 & 1.71 & 2.03 & 2.17 & 2.44 \\
\hline ROS & 2.07 & 1.91 & 3.21 & 3.95 & 2.22 & 2.28 & 4.75 & 3.54 \\
\hline ROA & -2.04 & 3.02 & 3.85 & 2.01 & 0.55 & 0.71 & 2.96 & 2.22 \\
\hline Profit Margin & -2.01 & 2.68 & 3.73 & 2.08 & 0.61 & 0.76 & 2.96 & 2.06 \\
\hline $\begin{array}{l}\text { Inventory } \\
\text { Turnover }\end{array}$ & 4.75 & 7.01 & 5.75 & 6.49 & 6.05 & 6.61 & 6.39 & 6.84 \\
\hline $\begin{array}{l}\text { Assets } \\
\text { Turnover }\end{array}$ & 1.01 & 1.13 & 1.03 & 0.97 & 0.90 & 0.94 & 1.00 & 1.08 \\
\hline AR Turnover & 5.49 & 4.64 & 5.36 & 4.96 & 4.36 & 4.55 & 4.92 & 4.85 \\
\hline
\end{tabular}

\section{Conclusion}

Implementation of Enterprise Resources Planning (ERP) systems in organizations in developed countries is an issue that has been in focus of interest over decade ago. The situation in Macedonia even though a bit time delayed is following the same path. The research of the ERP implementation by the factory "Komuna" chronologically followed through the period of seven years lead to conclusion that determining the ERP implementation effect on the company efficiency is rather complex task. As the ERP system is not isolated from the rest of the influences on organization, it is very complicated to assign certain advantages and disadvantages solely to its introduction. More precisely, using three different techniques for the case study method the results showed the following:

The conducted interviews with the managerial stuff revealed the changes that the system brought: different processes gained on competitiveness, the organization gained better visibility and monitoring of activities, improved decision making, improved serving of the customers, organization and optimization of the processes and of the production cycle.

On the other side the interview with the employees showed that employees see benefit in using the system and fair percentage of them use it even though their work position does not require that. The largest percent of them state that using of the system is very important for their work. Some reactions have been evident within the departments where the system reduced the previously existing privileges- taking of the power. The employees also state that the system made accomplishing of their tasks easier, as well as it brought speed in accomplishing of their work. The largest percent of the respondents don't feel that the system made them more confident about accomplishing of their tasks, but feel that it is interesting for their tasks. Regarding the financial indicators, their movement does not give good information for making conclusions. The only indicator which shows characteristic movement through the years is Labor productivity. Following this indicator constant inclination can be noticed which indicates increasing of the employee productiveness. Employees' 
number declines from 473 in 2001 to 305 in 2008; whilst the results show that they are becoming more productive. Summarizing all this effects it can be said that ERP systems implementation like in the case presented require time, money and will of management, but the effect is improvement of the company's efficiency, which further on helps in transformation of the ownership capital and more than all better market competitiveness. Generalization of the results should be given careful consideration, because the research is done for single case. According to (Garson, 2008), no generalization to a population beyond cases similar to those studied should be made. This means that the results of this research are applicable to the companies of similar size, production oriented. For this kind of companies it is justifiable to be said that if properly conducted, the implementation of ERP solutions will bring efficiency improvement.

\section{References}

1. Shanks, G., Seddon, P.: Enterprise resource planning (ERP) systems. J. of Information Technology 15, 243-244 (2000)

2. Bah, E., Brada, J.C., Yigit, T.: With a little help from our friends: The effect of USAID assistance on SME growth in a transition economy. J. of Comparative Economics 39, 205-220 (2011)

3. PWC, Guide to Doing Business and Investing in Macedonia (2008)

4. Yin, R.K.: Case Study Research: Design and Methods, 3rd edn., vol. 5. Sage Publications, Inc., Thousand Oaks (2003)

5. Sarker, S., Lee, A.S.: Using a case study to test the role of three key social enablers in ERP implementation. Inf. \& Man. 40, 813-829 (2003)

6. Myers, M.D.: Qualitative research in information systems. MISQ 21, 241-242 (1997)

7. Arksey, H.P.T., Knight, P.T., Knight, P.: Interviewing for social scientists: an introductory resource with examples. SAGE (1999)

8. Markus, M.L.: Power, Politics, and MIS Implementation. Comm. of the ACM 26, 430-444 (1983) 